\title{
Displacement field and fault model for the September 7, 1999 Athens earthquake inferred from ERS2 satellite radar interferometry
}

\author{
C. Kontoes, P. Elias and O. Sykioti \\ National Observatory of Athens, Institute for Space Applications and Remote Sensing, Athens, Hellas \\ P. Briole and D. Remy ${ }^{1}$ \\ UMR-CNRS 7580, Département de Sismologie, Institut de Physique du Globe de Paris, Paris, France
}

\author{
M. Sachpazi \\ National Observatory of Athens, Institute for Geodynamics, Athens, Hellas

\section{G. Veis and I. Kotsis} \\ National Technical University of Athens, Department of Surveying Engineering, Athens, Hellas
}

\begin{abstract}
On September 7, 1999, a moderate $\left(M_{w}=5.9\right)$ normal faulting earthquake occurred in the northwest of Athens (Hellas) causing heavy damages and casualties. Using interferometric combinations of ERS2 SAR images, we analyzed the coseismic deformation field. Two fringes are observed south of the Fili mountain, up to the coastline of the Elefsis gulf. They correspond to $56 \mathrm{~mm}$ increase in slant range. Modeling the earthquake as a dislocation in an elastic half-space, we inverted the interferometric data to assess the fault location and geometry and the amplitude of the coseismic slip. The model suggests $\sim 300 \mathrm{~mm}$ slip on an 18 $\mathrm{km}$ long blind fault composed of two pieces. The intersection of the fault plane with the Earth surface is located in the Fili mountain with $\mathrm{a} \sim \mathrm{N} 120^{\circ}$ orientation.
\end{abstract}

\section{Introduction}

On September 7, 1999 at 11:56:51 UT, a magnitude $M_{w}=5.9$ earthquake struck the area of Attica. It was strongly felt by the Athenian population, caused heavy damages and made several buildings collapse killing 143 people. It was the most damaging event in Greece since that of Cephalonia (August 12, 1953). Its epicenter is located at $38.08^{\circ} \mathrm{N}$; $23.58^{\circ} \mathrm{E}$, only $\sim 20 \mathrm{~km} \mathrm{NNW}$ from the Athens center. It is the one nearer to Athens, compared to the 1914 one which destroyed Thiva and the 1981 Alkyonides one at the East of the Gulf of Corinth. In the epicenter area south dipping normal faults are clearly expressed on the seismotectonic map. Two parallel normal faults dominate the neotectonic behavior of this region: a $120^{\circ} \mathrm{N}$-striking fault referred to as Aspropyrgos fault (F1), and a $110-130^{\circ} \mathrm{N}$-striking structure referred to as Fili fault (F2) [Pavlides et al., 1999]. This latter lies $\sim 5 \mathrm{~km}$ to the north of the Aspropyrgos fault (Plate la). These tectonic structures are roughly perpendicular to the

\footnotetext{
Now at Institut de Recherche pour le Developpement (IRD), Bondy, France

Copyright 2000 by the American Geophysical Union.
}

Paper number 2000 GL008510.

0094-8276/00/2000GL008510\$05.00
$\mathrm{N} 26^{\circ}$ extension stress field measured by GPS [Clarke et al., 1998].

The absence of any seismic rupture at the surface after the earthquake did not allow a direct field identification of the seismogenic fault. Seismic networks installed immediately after the earthquake were used to record the aftershock activity. At the same time a parallel operation using radar interferometry was initiated, to measure and analyze the surface deformation.

\section{Co-seismic Surface Deformations Captured by the ERS2 Satellite}

Interferometric analysis of SAR images has demonstrated potential to monitor and measure surface deformations associated with earthquakes [Massonnet et al., 1993; Zebker et al , 1994; Murakami et al., 1996]. It has been used for the study of the $M_{w}=6.6$ May 13,1995 , Kozani, and $M_{w}=6.1$ June 15, 1995, Aigion earthquakes in Greece [Meyer et al., 1996; Bernard et al., 1997].

The selection of the interferometric pairs was based on their sensitivity to the topography, expressed by the altitude of ambiguity $\left(h_{a}\right)$, that is the change in elevation, which results in a parasitic fringe $(28 \mathrm{~mm})$. Only image pairs with $h_{a} \geq 5$ times the expected DEM error were processed, in order to limit the residual topographic fringes to a low magnitude. Table 1 illustrates the time spanning of the interferometric pairs used and their corresponding $h_{a}$ values. In this study the elimination of the topography was done by subtracting a synthetic fringe pattern produced by using a $\pm 10 \mathrm{~m}$-accuracy Digital Elevation Model (DEM) from the interference pattern resulted by the two SAR images. The DEM of the study area was produced, by digitizing elevation data from 1:5000 scale maps. Its accuracy was checked by a set of points with known elevation. One should note that the $h_{a}$ values of the four coseismic interferograms range between $50 \mathrm{~m}$ to $133 \mathrm{~m}$, resulting in topographic artifacts between $5.6 \mathrm{~mm}(0.2$ phase cycles) and $2.1 \mathrm{~mm}(0.075$ phase cycles) respectively.

The interferograms, calculated using the DIAPASON (CNES) software, span the periods [Dec. 28, 1995 to Sept. 23, 1999], [Nov. 27, 1997 to Sept. 23, 1999] (Plate 1c) and [Sept. 19, 1998 to Oct. 9, 1999] (Plate 1d). They clearly show that the main shock and aftershocks have induced a coseismic 


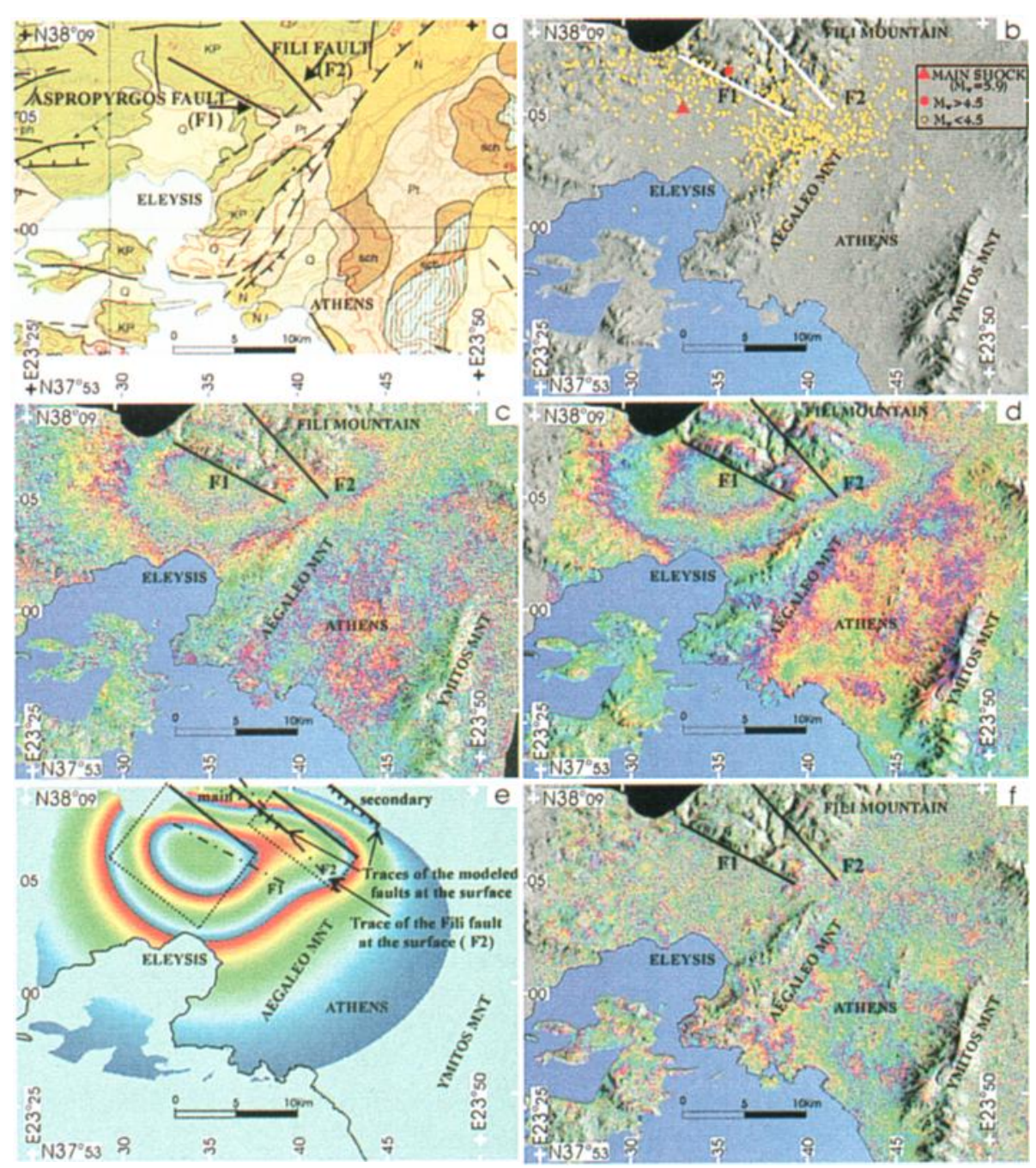

Plate 1. (a) Seismotectonic map of Athens with seismogeological elements. The Aspropyrgos (F1) and Fili (F2) faults are indicated. (b) Distribution of aftershocks recorded by the Geodynamics Institute of the National Observatory of Athens (NOA) array. (c, d) Coseismic interferograms spanning the periods [Nov. 27, 1997 to Sept. 23, 1999] and [Sept. 19, 1998 to Oct. 9 , 1999]. (e) Modeled interferogram calculated by least square inversion of the fringes in Plates 1c and 1d. The two modeled fault segments and their traces on the surface, as well as the mapped Aspropyrgos (F1) and Fili (F2) faults are illustrated. (f) Preseismic interferogram spanning the period [July 22, 1995 to July 15, 1999].

surface deformation, which appears with at least two concentric, but not symmetric fringes (equivalent to $56 \mathrm{~mm}$ in slant range), centered at $38.10^{\circ} \mathrm{N} ; 23.60^{\circ} \mathrm{E}$. This center is located at a distance of less than $3 \mathrm{~km}$ away from the main epicenter.

The fringes are not artifacts due to DEM errors or other tropospheric effects. Indeed, their number and concentric pattern remain the same in all interferograms, although they have different $h_{a}$ values $(133 \mathrm{~m}, 67 \mathrm{~m}$, and $50 \mathrm{~m})$ and they are issued from images acquired on two adjacent tracks, namely 465 (Plate 1c) and 236 (Plate 1d). It should be noted that the slightly different $\left(-5^{\circ}\right)$ line of sight angle for the tracks 236 and 465 , is not enough to produce significantly different fringe patterns. We have estimated that the maximum expected effect in slant range displacements due to this difference in the viewing geometry, is less than $1.1 \mathrm{~mm}$, which may be neglected in regards to the DEM errors and other possible troposphere artifacts. It is also worth-noting that the four preseismic interferograms (Table 1) do not show any fringes (Plate $1 \mathrm{f}$ ).

\section{Modeling the Observed Deformation Field}

The fringes shown in Plates $1 \mathrm{c}$ and $1 \mathrm{~d}$ were used to sample slant range displacements at 134 discrete points along them, approximately one sample every $300 \mathrm{~m}$. These data were used as input to run an inversion model, assuming dislocations of rectangular planes in an homogeneous elastic half-space [Okada, 1985]. Table 2 shows the variables used in the model. The inverse algorithm is that developed by Briole et al. [1986] using the least squares approach proposed by Tarantola and Valette [1982]. The inversion program was run first assuming a single rectangular fault, but the model could not correctly fit the asymmetry at the eastern end of the fringe pattern. Therefore a secondary fault was added in order to fit better the observed fringes.

Mostly due to the trade-off between strike slip and strike angle, the data inversion could not be done with all parameters free. Only by fixing one of the two values the stability of the inversion algorithm could be obtained. Therefore, two models were examined. In the first one (model 
Table 1. ERS2 Image Combinations Used for Interferometric Calculations. The Line of Sight Vectors are $(0.358 \mathrm{E},-0.077 \mathrm{~N}$, $0.930 \mathrm{U})$ and $(0.427 \mathrm{E},-0.089 \mathrm{~N}, 0.899 \mathrm{U})$ for Tracks 236 and 465 Respectively

\begin{tabular}{cccc}
\hline Date of Image 1 & Date of Image 2 & $h_{a}(\mathrm{~m})$ & Satellte Track \\
\hline Dec. 1995 & July 1999 & 108 & 236 \\
Dec. 1995 & Nov. 1997 & 81 & 236 \\
Nov. 1997 & July 1999 & 325 & 236 \\
Dec. 1995 & Sept. 1999 & -133 & 236 \\
Nov. 1997 & Sept. 1999 & -50 & 236 \\
July 1999 & Sept. 1999 & -60 & 236 \\
July 1995 & July 1999 & 51 & 465 \\
Sept. 1998 & Oct. 1999 & -67 & 465 \\
\hline
\end{tabular}

1), all parameters were kept free except for the strike slip that was forced to zero (pure normal faulting). In the second one (model 2), the strike and dip angles were fixed at $116^{\circ}$ and $54^{\circ}$ respectively, so as to conform to the focal mechanism of the earthquake [Tselentis and Zahradnik, 1999; Papadopoulos et al., 2000] and with the orientation of the known tectonic structures [Pavlides et al., 1999]. Moreover, the model accounts for a lateral strike slip that was also observed in some aftershocks occurred within the month following the main shock [Papadopoulos et al., 2000].

Both models fit the observed fringes well. The root-meansquare (rms) error for fitting the 134 sampled data, is $4 \mathrm{~mm}$ for model 1 (0.14 fringes). However, the suggested strike $\left(100^{\circ}\right)$ and dip $\left(43^{\circ}\right)$ angles (Table 3 ), are not consistent with the preliminary fault plane solutions indicating strike directions and dip angles in the ranges of $113^{\circ}-119^{\circ} \mathrm{N}$ and $52^{\circ}-56^{\circ}$ respectively [Tselentis and Zahradnik, 1999; Papadopoulos et al., 2000]. Model 2 fits the data with a rms of $5.5 \mathrm{~mm}$ ( 0.19 fringes), which is still in the range of the expected errors due to DEM or other tropospheric perturbations. Although the fixing of the dip angle in model 2 was not mandatory, we did so, because this parameter was poorly constrained by the inversion and because values ranging between $48^{\circ}$ and $55^{\circ}$, gave solutions fitting the data equally well. Table 4 gives the fault parameters obtained by model 2 and the corresponding uncertainty values. According to model 2, the main fault segment is responsible for the $80 \%$ of the total energy released $\left(12.110^{17} \mathrm{~N} \mathrm{~m}\right)$, while the secondary fault segment for the rest $20 \%\left(2.510^{17} \mathrm{~N} \mathrm{~m}\right)$. The total moment $\left(14.610^{17} \mathrm{~N} \mathrm{~m}\right)$ is in good consistency with the seismic moment deduced from the seismological data (7.8 $10^{17} \mathrm{~N} \mathrm{~m}$ for USGS, $1210^{17} \mathrm{~N} \mathrm{~m}$ for Harvard). A difference in favor of the geodetic moment has been observed in similar studies [Wright et al., 1999, Bernard et al., 1997] in the past.

Both fault segments (main and secondary) are well constrained in location, azimuth, depth and slip. According to
Table 2. Parameters Describing the Fault Geometry and Motion in the Okada Formalism

\begin{tabular}{cc}
\hline Symbol & Description \\
\hline Lat, Lon & Latitude and Longitude of the fault upper edge center \\
$\alpha, \theta$ & Strike and dip angles $\left(^{\circ}\right)$ \\
H & Depth of the upper edge of the fault $(\mathrm{km})$ \\
D, L & Half-length and width of the fault $(\mathrm{km})$ \\
S, D & Strike (positive left lateral) and dip (positive normal) \\
& slips (mm) \\
\hline
\end{tabular}

the model most of the observed surface deformations are due to a dip-slip along the main fault segment. The secondary fault segment, which is responsible for the observed asymmetry of the deformation field, corresponds to a shallower rupture. This segment is located in the areas where the major damages were reported. The energy centroid depth is $10.3 \mathrm{~km}$ for the main fault, and $5.4 \mathrm{~km}$ for the secondary one. The weighted average centroid depth is $9.5 \mathrm{~km}$. The two fault segments, intersect the Earth surface at points: $38.18^{\circ} \mathrm{N}$; $23.55^{\circ} \mathrm{E}-38.14^{\circ} \mathrm{N} ; 23.66^{\circ} \mathrm{E}$ (main fault) and $38.16^{\circ} \mathrm{N}$; $23.66^{\circ} \mathrm{E}-38.12^{\circ} \mathrm{N} ; 23.75^{\circ} \mathrm{E}$ (secondary fault). These two traces lie at $5 \mathrm{~km}$ and $7.5 \mathrm{~km}$ to the north of the Aspropyrgos fault at the southern base of the Fili mountain. Plate le shows the synthetic interferogram derived from model 2 , as well as the mapped (F1 and F2) and modeled fault segments.

\section{Discussion}

The co-seismic interferograms show that the affected area is extended for more than $20 \mathrm{~km}$ in the E-W and $10 \mathrm{~km}$ in the $\mathrm{N}-\mathrm{S}$ directions and is bounded by the Fili mountain in the NE and the Aegaleo mountain in the SE (Plates $1 \mathrm{c}$ and $1 \mathrm{~d}$ ). This area encompasses most of the aftershock locations, which extend SW to the modeled faults with a WNW-ESE direction, similar to that of the tectonic structures (Plate $1 \mathrm{~b}$ ).

The absence of rupture propagation towards the Earth surface made difficult the direct identification of the seismogenic fault. Field investigation $[N N$. Ambraseys, internal field report] confirms that neither the Aspropyrgos nor the Fili faults exhibit evidence of shallow reactivation. According to our model the main fault segment is located at the NW extension of the Fili fault, as mapped by Pavlides et al. [1999]. It experienced a $\sim 300 \mathrm{~mm}$ slip at a depth ranging between 16 and $6 \mathrm{~km}$. Towards the east, the modeled fault segment intersects the surface $\sim 3 \mathrm{~km}$ to the north of the Fili fault (Plates 1c and 1d). We argue that a secondary structure was activated there, that could be either the southeastern termination of the main plane not co-planar to it, or a secondary structure. In both cases, the secondary plane does not intersect the Earth surface where the Fili fault is currently mapped, but $\sim 3 \mathrm{~km}$ to the north of it. The modeled faults do

Table 3. Fault Parameters Derived by Model 1 (Strike Slip $=0$, Other Parameters Free)

\begin{tabular}{cccccccccc}
\hline Fault & Lat $\left({ }^{\circ}\right)$ & Lon $\left({ }^{\circ}\right)$ & $\mathrm{h}(\mathrm{km})$ & $\mathrm{d}(\mathrm{km})$ & $\mathrm{L}(\mathrm{km})$ & $\theta\left(^{\circ}\right)$ & $\alpha\left(^{\circ}\right)$ & $\mathrm{D}(\mathrm{mm})$ & $\mathrm{M}(\mathrm{N} \mathrm{m})$ \\
\hline Main fault & $38^{\circ} 6^{\prime} 54^{\prime \prime}$ & $23^{\circ} 33^{\prime} 58^{\prime \prime}$ & 7.5 & 5.6 & 7.4 & 43 & 100 & 470 & $11.710^{17}$ \\
Uncertainty & $6.6^{\prime \prime}$ & $13.3^{\prime \prime}$ & 0.7 & 0.4 & 0.8 & 4 & 3 & 35 & \\
Secondary fault & $38^{\circ} 6^{\prime} 30^{\prime \prime}$ & $23^{\circ} 41^{\prime} 5^{\prime \prime}$ & 3.7 & 3.9 & 1.3 & 43 & 100 & 400 & $1.210^{17}$ \\
Uncertainty & $10^{\prime \prime}$ & $16.6^{\prime \prime}$ & 0.4 & 0.5 & 0.4 & 6 & 7 & 25 & \\
\hline
\end{tabular}


Table 4. Fault Parameters Derived by Model 2 (Strike Angle $=116^{\circ}$, Dip Angle $=54^{\circ}$, Other Parameters Free)

\begin{tabular}{ccccccccccc}
\hline Fault & Lat $\left(^{\circ}\right)$ & Lon $\left(^{\circ}\right)$ & $\mathrm{h}(\mathrm{km})$ & $\mathrm{d}(\mathrm{km})$ & $\mathrm{L}(\mathrm{km})$ & $\theta\left(^{\circ}\right)$ & $\alpha\left(^{\circ}\right)$ & $\mathrm{S}(\mathrm{mm})$ & $\mathrm{D}(\mathrm{mm})$ & $\mathrm{M}(\mathrm{N} \mathrm{m})$ \\
\hline Main fault & $38^{\circ} 7^{\prime} 33^{\prime \prime}$ & $23^{\circ} 35^{\prime} 04^{\prime \prime}$ & 5.9 & 5.2 & 11.0 & 54 & 116 & 50 & 350 & $12.110^{17}$ \\
Uncertainty & $6.6^{\prime \prime}$ & $10^{\prime \prime}$ & 0.6 & 0.3 & 1.0 & - & - & 25 & 30 & \\
Secondary fault & $38^{\circ} 7^{\prime} 23^{\prime \prime}$ & $23^{\circ} 41^{\prime} 14^{\prime \prime}$ & 4.0 & 4.5 & 3.5 & 54 & 116 & 35 & 260 & $2.510^{17}$ \\
Uncertainty & $6.6^{\prime \prime}$ & $13.3^{\prime \prime}$ & 0.4 & 0.4 & 0.4 & - & - & 15 & 20 & \\
\hline
\end{tabular}

not appear on the existing geological and seismotectonic maps and they suggest the existence of a blind fault zone. The absence of a shallow dislocation explains why the deformation does not exceed two fringes, although the estimated slip is $-300 \mathrm{~mm}$. The upper part of the crust did not rupture during the earthquake and the mode of deformation of this layer needs further examination. We believe that long term seismic risk assessment in Athens, requires better knowledge on the seismic/aseismic deformation processes at shallow depths of the active tectonic structures in the vicinity of the city.

Acknowledgements. Thanks are due to Prof. N.N. Ambraseys for making available to us his internal field report on the Athens earthquake. We are grateful to the European Space Agency (ESA) for providing ERS2 SAR data. Sincere thanks to Dr. G. Stavrakakis, director of the Geodynamics Institute of NOA for providing the aftershock data recorded in the period September 8, to October 5 1999. Thanks are due to H. Vadon and K. Feigl for their support in using DIAPASON tool (CNES), A. Avallone (IPGP) for his contribution to the fault modeling, and the referees for their helpful comments on the paper. IPGP contribution $n^{\circ} 1698$.

\section{References}

Bernard, P. et al., The Ms=6.2, June 15, 1995, Aigion earthquake (Greece): Evidence for low normal faulting in Corinth rift, $J$ Selsmology, l, 131-150, 1997.

Briole P., G. De Natale, R. Gaulon, F. Pingue and R. Scarpa, Inversion of geodetic data and seismicity associated with the Friuli earthquake sequence (1976-1977), Annales Geophysicae, 4, 481-492, 1986.

Clarke, P. J. et al., Crustal strain in central Greece from repeated GPS measurements in the interval 1989-1997, Geophys J. Int, 134, 195-214, 1998.

Massonnet, D., M. Rossi, C. Carmona, F. Adragna, G. Peltzer, K. Feigl, and T. Rabaute, The displacement field of the Landers earthquake mapped by radar interferometry, Nature, 364, 138$142,1993$.

Meyer, B., R. Armijo, J. B. Chabalier, C. Delacourt, J. C. Ruegg, J. Achache, P. Briole, and D. Papanastassiou, The 1995 Greneva (Northern Greece) Earthquake: Fault model constrained with tectonic observations and SAR interferometry, Geophysical Research Letters, 23(19), 2, 677-2, 680, 1996.
Murakami, M., M. Tobita, S. Fujiwara, T. Saito, and H. Masaharu, Co-seismic crustal deformations of the 1994 Northridge, California, earthquake detected by interferometric JERS 1 Synthetic Aperture Radar, Journal Geophysical Research, 101, 8605-8614, 1996.

Okada, Y., Surface deformations due to shear and tensile faults in a half-space, Bull. Seism. Soc. Am, 75, 1135-1154, 1985.

Papadopoulos, G.A., G. Drakatos, D. Papanastassiou, I. Kalogeras, and G. Stavrakakis, Preliminary results about the catastrophic earthquake of 7 September 1999 in Athens, Greece, Seismological Research Letters, 71. 3, 318-329, 2000.

Pavlides, S., G.A. Papadopoulos, and A. Ganas, The $7^{\text {th }}$ September, 1999 unexpected earthquake of Athens: Preliminary results on the seismotectonic environment, paper presented at $l^{\text {st }}$ Conf. Advances in Natural Hazards Mitigation Experiences from Europe and Japan, Programme-Abstracts-Reports, 80-85, 1999.

Tarantola, A., and B. Valette, Generalized nonlinear inverse problem solved using the least squares criterion, Rev. Geophys Space Phys, 20, 219-232, 1982.

Tselentis, G.A., and J. Zahradnik, The Athens earthquake of September 7, 1999, paper submitted to Bull. Seism. Soc. Am., 1999.

Wright, T.J., B.E. Parsons, J.A. Jackson, M. Haynes, E.J. Fielding, P.C. England, and P.J. Clarke, Source parameters of the 1 October 1995 Dinar (Turkey) earthquake from SAR interferometry and seismic body wave modeling, paper submitted to Elsevier Preprint, 1999.

Zebker, H.A., P.A. Rosen, R.M. Goldstein, A. Gabriel, and C.L. Werner, On the derivation of co-seismic displacement fields using differential radar interferometry: The Landers earthquake, $J$. Geophys. Res., 99, 617-19,634, 1994.

C. Kontoes, P. Elias and O. Sykioti, National Observatory of Athens, Institute for Space Applications and Remote Sensing, Metaxa \& Vas. Pavlou, 152 36, Palea Penteli, Athens, Hellas.

(kontoes@creator.space.noa.gr).

P. Briole and D. Remy, UMR-CNRS 7580, Département de Sismologie, Institut de Physique du Globe de Paris, 4 Place Jussieu, 75005 Paris, France. (briole@ipgp.jussieu.fr).

M. Sachpazi, National Observatory of Athens, Institute for Geodynamics, Lofos Nimfon, 11810 Athens, Hellas.

(m.sachp@egelados.gein.noa.gr).

G. Veis and I. Kotsis, National Technical University of Athens, Department of Surveying Engineering, 15780, Athens, Hellas. (inveis@otenet.gr).

(Received February 8, 2000; revised June 7, 2000; accepted September 14, 2000.) 